\section{Research Article}

(C) 2021 Salamun et al. This is an open access article licensed under the Creative Commons Attribution-NonCommercial 4.o International License

(https://creativecommons.org/licenses/by-nc/4.o/)

\title{
Rabbani Political Leadership for Sustainable Development: A Case Study in Terengganu, Malaysia
}

\author{
Hailan Salamun ${ }^{1}$ \\ Firdaus Khairi Abdul Kadir' \\ Asyraf Hj Ab Rahman' \\ Rofishah Hj Rashid ${ }^{2}$ \\ ${ }^{1}$ Centre for Fundamental and Continuing Education, \\ Universiti Malaysia, Terengganu, Malaysia \\ ${ }^{2}$ Teachers' Training Institute, Dato' Razali Ismail Campus, \\ Kuala Terengganu, Terengganu, Malaysia
}

DOI: https://doi.org/10.36941/ajis-2021-0124

\begin{abstract}
The objective of the current study was to clarify the role of 'Rabbani' to establish a balance of sustainable development in Terengganu political leadership, Malaysia. We propose Rabbani political leadership as a task of bridging the understanding of sustainable development in harmony that may influence followers to manage the development in political workplace. It then explores the underlying reason for the mobilisation of sustainable social development. This study classified as a fieldwork study based in Terengganu, Malaysia. The obtained data were analysed systematically according to selected themes. The argument constructed into the following stages, namely an overview of Islamic principles in setting an identity of Islam as the way of life, proposing unity as the foundation of a harmonious life in which the whole life system as a response to having a holistic development as a catalyst of progress. This study was able to benefit the local community of Terengganu and also amongst the rulers and politicians in order to understand and applying the value of Rabbani political leadership quality for the sake of better social lifestyle. Rabbani political leadership in the state of Terengganu could be one of the models that cover three types of political leadership work ethics in Islamic principles namely; building identity that Islam is the way of life; proposing unity ass the foundation of a harmonious life; and a holistic development as a catalyst of progress.
\end{abstract}

Keywords: Rabbani political leadership; Sustainable development, Politics in Terengganu

\section{Introduction}

Over the last few years, there are organizations put the primary concern on some components of sustainability in its policy and strategy. World Commission on Environment and Development (WCED) asserts human need as the vital component of sustainable development which covers three key areas; the economic growth, conservation of natural resources and the environment, and social development. In Islam, the concept of human needs is based on the principles that all the sources in 
human life were created by God. Hence, human needs embody two main aspects namely, physical needs and spiritual needs.

Ironically, the term sustainable development has been used differently, depending on the way it is interpreted and sometimes contradictory based on the type of organizations and knowledge disciplines. This phenomenon will affect the concept of the sustainable development which it drew to the ambiguously worded. Then, the term sustainable development could be synthesized as the assurance of the future development on progress and evolution of the future generation. Hence, there is a relationship between sustainable development and leadership. The leader may take role as a bridge to harmonize the understanding of sustainable development who has power to manage the development in any organizations. A leader does the right things and will manage things right. However, leaders' personality and behaviour are always separated in any leadership literatures. Most of the research on leadership places considerable emphasis on specific attributes to identify the effective leaders from others (Stogdill, 1974). When the term 'religious' is added with leadership, it leads to spirituality or worship rituals. In Islam, the term 'religious' means the combination of spirituality and construct guidelines for human relations in the worldly life. This paper is designed to clarify the role of 'Rabbani' to establish a balance of sustainable development from Terengganu political leadership perspective.

\section{Literature Review}

Rabbani leadership discusses the direction that emphasises mutual responsibility and accountability by representing leadership practices motivated by moral considerations and thoughts in order to attain the pleasure of Allah. Rabbani is underpinned by the paradigm of tawhid or Oneness of Allah (Ramli Awang, 1997) that leaders share responsibilities and accountability, who practices the internal drives aligned to concerns for godly/divine righteousness, humanity, and human life development (Salamun \& Shah, 2012). In the Islamization of the leadership concept, the tawhidic approach is needed to enact justice and fairness in managing people as the aim of man's creation in this world is to give full submission to Allah (Jabnoun, 1994; Abdul Hamid, 2007).

\subsection{Rabbani Political Leadership}

Rabbani concept used in the Malay political leadership is an attempt to shape the direction of the leader and the followers (Salamun, Aziz, Rahman \& Rashid, 2018). According to Abu Faris, M.A.Q. (200o), responsible leaders are caring for the public, including religious, economic, social, educational and political sphere. Ali (2009) notes that the leader is responsible for maintaining the religion by upholding Islam, being fair and upholding the law of Allah on this earth. Therefore, the leader must be appointed to govern human affairs and to be called a political leader who led the calling for good deeds and put aside the wrongdoing (A. Rahman, 2012). Political leadership implies followership, as well as group tasks, to accomplish innovative adaptation in a specific situation and institutional culture. Politics is a combination of economic, social and political leadership in which political leadership touches on the legitimacy of a political leader's power. Hence, political leadership may, therefore, becomes a form of competitive political activities which abundance of ideas and values, sometimes stressing structural leadership, intellectual leadership or charismatic leadership (Joseph et al., 2009). It clearly showed that good political leaders could fulfil their responsibilities correctly to guide and assist those who are being led to enhance ethical values and strengthen the organisation.

The perfect example of Rabbani political leadership can be seen through the credibility of Prophet Muhammad (pbuh). He exemplified the superior character of his command by combining knowledge, ethics, noble and souls, and strengthening the unity and skills of the people (Amir, 2009). The role of a leader can be exercised by the centralisation of power or through political leadership (Al-Maududi, 2000; Cheema \& Shahbaz Ahmad, 2013). Power refers to the abilities and characteristics 
of the government. A sovereign government must exercise responsibility for its subordinates to gain the trust and confidence of its subordinates to continue to rule (Hamdan Aziz, 2012). With the centralisation of power by the government, then the government needs to exercise leadership to govern, especially in political affairs. Political leadership is fundamental to the governance, preservation, political stability and survival of the human race on earth (Abd Jalil Borhan, 2013).

\subsection{Sustainable development}

The Holy Qur'an and the hadith mentioned the terminology of sustainable development for centuries. Islam seeks to set a balance value between the economic, environment, and social dimensions. It could be comprehended on the needs of a multi-dimensional process towards establishing the value of balance. This kind of process is needed to balance between economics and social development, and the environment, respectively. Muslims believe and support eradicating poverty 'through balanced economic growth, strengthening the Muslim's faith, and raising the status of Islam in the world. In Islam, a leader needs to struggle to put a clear balance between individual influence and social responsibilities. In Islamic perspective, working is part of obligatory activity besides its value in bridging the light of person's need and necessity to establish equilibrium in one's individual and social life (Nor Azzah Kamri et al., 2014). Hence, it is important to set a balance between material and spiritual needs to become an ideal and virtuous person, and not the wealthiest or most potent individuals (Dion, 2002, A. Rahman,2018). The healthy person is one who is balanced in all dimensions and brings about socio-economic well-being and harmony with the environment.

Leaders may help their team strike a balance- in this case, a balance between political needs and religious teachings. According to Stavrou \& Ierodiakonov (2011), seeking more balanced lifestyles is a primary driver of flexibility. Hence, Islam seeks the equitable in man and then guides man to maintain that balance in society and the eco-system, which plays host to the human community. Previous theory and research indicate that striking a balance is perfectly done whenever the usage of the natural environment happened without involving unnecessary destruction of the government and civic society. Hence, these are the chance to revive the relationship between human being and the environment (Aburounia \& Sexton, 2006). Political leaders for sustainability development should always have a sense of responsibility and trust in exercising leadership to balance the faith, 'syariah' and ethic. The leader needs to exercise the ethical, values-based leadership towards pursuing the economic and societal progress. According to Nik Mustapha Nik Hassan (200o), political leadership within Malay Muslims must have all these characteristics; 1-mastering the knowledge of Islam according to the Quran and hadith, 2- be able to translate the greatness of Islam, 3-make Islamic principles as the foundation, 4-able to form knowledgeable societies and 5-should be open-minded and always support the truth. The objective of the current study was therefore to determine the attributes of political leadership in Terengganu state for the sustainable development perspective.

\subsection{Politics in Terengganu}

The arrival of Islam to the Malay region contributed to the birth of Malay Civilization. Historical evidence shows that the Terengganu Inscription Stone found in Kuala Berang indicate that the Muslim community has long practised Islamic law. During these stages of development, the Malay political leadership influenced by the teachings of Islam (Salamun et al., 2018). Islam has shaped the lives of the community to influence the way of life, including the relationship between leaders and followers or the local community.

The emergence of Malay Civilization began when the first Sultan of Malacca, Sultan Megat Iskandar Shah accepted Islam. Then the majority of the Malay community accepted Islam and practices Islamic teaching in their life. The 'Sultan' and people's relationship was so close that the sultan's position of power was honoured such as to carry the divine trust and the loyalty of the people to him (Suffian Mansor, 2010; Sulastry Yurni Noor Ahmad \& Mohd Nor Azila Aidit, 2013; Indah 
Matsuri, 2015). The power of the 'sultan' or King was limited when the British had taken control of the government, including the state of Terengganu. Leaders no longer come from the King's family, but the locals deserve to be leaders if they are active in the political arena. The political paradigm shift led to conflict as the British gained a new understanding that separated the administration and leadership from religious teachings. Secular is a new understanding separates state affairs from interfering with religious practices. All governmental authorities should be referred to political positions, while the king was referred or consulted merely on religious and customs matters. All matters of life such as political system, education, administration, economy and law are under the jurisdiction of the Chief Minister, while religious issues involving family, worship are subject to the department of religion (Azmi Aziz Mostafa Kamal Mokhtar, 2011; Mashitah Sulaiman, 2013).

Political developments that occurred in the state mostly linked to protecting Islam. Therefore, the people of Terengganu are very concerned about electing their leader during elections, and competing political parties will find it difficult to compete with the issues that are taking place (Azmah Abd. Manaf, 2013). Looking at the Terengganu by-election in the first general election after the independence of 1959, the Malay political parties, PAS (The Pan-Malaysian Islamic Party, (Parti Islam Se-Malaysia) ) discovered as winning political party defeated UMNO (The United Malays National Organisation, (Pertubuhan Kebangsaan Melayu Bersatu) ) and in 1964 UMNO won the state election until 1999 PAS again seized the state government. However, in the 2008 and 2013 general elections, PAS was defeated, although, the party managed to win the Terengganu state of government in 2018 general election.

\section{Methodology}

State of Terengganu, Malaysia was focused by the researchers to gain an in-depth understanding of the state's nature and rabbani political leadership model. This research aims to investigate some factors contribute to the effect of rabbani leadership in political workplace for sustainable development goal. The method used is a case study research which identifies a specific problem or case described. Descriptive analysis uses data based on relevant themes. Therefore, the findings data will not be generalized to other research. The selection of key informants in this study came from the leaders of PAS and UMNO political parties as news sources or how the nature of rabbani leadership was demonstrated to the public. They engage in political party activities at all levels and manifest the rabbani features and the involvement in political leadership practices. The study participants included a female and seven males amongst the party leaders and activists. The average duration of an interview was one hour in which the questions were open-ended questions. All the data were analysed according to selected themes specified in the study objectives.

\section{Results and Discussion}

\subsection{Rabbani Political Leadership in Terengganu}

The arrival of Islam to Malaya (now referred to as Peninsular Malaysia) contributed to the birth of Malay Civilization. Historical evidence shows that the Terengganu Inscription Stone found in Kuala Berang indicate that the Muslim community has long practised Islamic law. During these stages of development, the Malay political leadership influenced by the teachings of Islam (Salamun et al., 2018). Although Malaya was colonised by some countries like Portuguese, Dutch, British and Japanese, Islam has shaped the lives of the community to influence the way of life, including the relationship between leaders and followers or the local community.

The 2oth century was the most challenging period when the Siamese government handed over the Terengganu state rights to the British without consulting the sultan as the head of the state government. These are the main issues that the sovereignty needs to be resolved and amended by the state government policy (Nik Haslinda Nik Hussain, 2014). This effort may cause an initial approach 
to establish a body of state law, known as 'Itqanul Muluk Bi Ta'dilis Suluk' in the Arabic language is Malay Martial Law in 1911 (Ruhani Tuan Shariff, 1984; Nik Haslinda Nik Hussain, 2014). The establishment of this law is also to proof that Islam is rooted in Terengganu, thus Islamic law must guide all matters involving government by adherence, and the sovereignty of the country can be saved up to be able to maintain the status of the Malay Muslims until nowadays (Nik Haslinda Nik Hussain, 2014).

Hence, Rabbani concept has inspired the objective of the government's policy that emphasizes certain political thinking derived from religion. Rabbani leadership may inspire the practising Islamic teaching for selecting and producing quality human capital. In the early period, the Terengganu state applied these practices which have been shown to play a more significant role in producing many Islamic scholars such as Tok Pulau Manis, Guru Haji Hussein, Guru Haji Muhammad and Haji Mat Shafie. They have played a vital role within the palace and administration of the state of Terengganu. The involvement of these religious leaders in partisan politics was evident when the UMNO and PAS branches were established in Terengganu (Azmah Abd. Manaf, 2013).

\subsection{The notion of religious belief as a source of knowledge and guidance}

The notion of religious belief as a source of knowledge and guidance is well-known as the basis of the Islamic worldview. The concept of Tawhìd or belief in the oneness of God becomes the basis of faith driving Muslim to do his intentions, words and actions in accordance with the divine will. This continuous relationship connects life in the world and life in the hereafter. Therefore, every action of a Muslim contributes to the matter of goodness in his life.

To develop the obedient person in leadership, Beekun \& Badawi (1999) states that leaders must uphold the principles of leadership with moral characters based on iman or faith. Leadership is a matter of responsibility and trust or 'Amanah' (Ahmed, 2009; Ali, 2009; Beekun \& Badawi 2009; Salamun \& Shah, 2012) rather than a privilege. The leader dedicates himself to guide, protect and deal with the followers with justice. The value of trust and responsibility will bring Muslims to accept the obligation of work and its consequences. In this sense, leaders may appreciate a task that offer responsiveness from others. Hence, political leaders should always be in direct communication toward other individuals through one-on-one relationships calling the balance in terms of the needs and affairs of life in the world with the hereafter.

For the Malay party, the struggle to defend religion, race and nation as embodied in the party constitution is fundamental to the exercise of their political leadership responsibilities. There are several statements made by the following study participants:

"Our struggle from the past to the present is not to run away from our constitution, to defend our religion, our nation and our country...Party trusts for the rights of the Malays ..." (private interview P1 $U)$

"In any party it is always a matter of winning, in order to give the party a seat to rule in the state or country; secondly, guarding the party so that it does not cause the party to lose its dignity and also educates the party members to have their responsibility not only for playing the party because of the material but for the struggle, as I said earlier, Islam which is religion, nation and homeland (country)" (private interview $P_{3} U$ )

Similarly, the Malay party, PAS, whose political leadership responsibilities also move in line with the party's policy of struggle as enshrined in the party constitution. The leadership responsibilities described based on the statements made by the study participants are as follows:

"I have worked hard to emphasise the members, in particular giving the members an understanding of the aims and objectives of the Pas itself ... knowing the basics of this Pas struggle for Islam, upholding the ideals of the Islamic State..." (private interview $P_{2} P$ ) 
Leaders not only direct followers to carry out the task given, but simultaneously help their followers by setting direction, build an inspiring vision, and create improvement to their organisation. The prophet Muhammad (pbuh) involved articulating, communicating and inspiring a view to all Muslims throughout an organisation or Muslim community. His courageousness, and the ability to take calculated risks are amongst the essential attributes of a leader. Being a successful leader, he or she should set a respectable and virtuous example and act as a role model for their team, standing up for the truth is a right and a responsibility. He was successfully captivating communication to transform individual goals into a shared organisation of Muslim's community or Ummah goals (Salamun et al., 2018). These attributes describe Rabbani behaviour, which promoted the concept of Tawhìd, or Oneness of God through cooperation, creativity and innovation. The way of life is a system of beliefs and practices initially revealed by Allah to prophet Muhammad which provides specific guidelines for all people to follow in their daily lives.

It is a useful criterion for assessing the 'holistic vision' that is innate in all beliefs and the importance attached to being in continuous relationship with God. Islam does not differentiate and separating between temporal and religious aspects of life. The previous thoughts or ideology will not control the worldview of people who accept Islam as a new way of life. They may refuse the doctrine like secularism, humanism, and liberalism, which are contradicts with the Islamic faith. The leader must have followers who can draw all people to know and understand Islam as a whole and reference centre of all aspects of life. It serves Muslims with comprehensive guidelines on personal and professional affairs management. Thus, Islam's view is that worldly life and the hereafter not separate from one another. Political leaders have focused primarily on the tactic individuals used to influence one another. Leaders often develop a unique, dear relationship with trusted followers ('usrah' in the politic network). Similarly, work in Islam is measured as a virtue that is considered part of the deeds of worship that must be performed by every Muslim. Islam strongly emphasizes that every ummah works because this practice contributes to the halal pursuit of sustenance. A person who has completed his task will provide satisfaction in life, in addition to being able to increase self - esteem to live in society.

\subsection{Unity as the foundation of a harmonious and sustainable life}

There is a growing field of research being undertaken using a discussion of Islam in sustainable social development. In Islam, the aims at building a socio-economy based upon religion, morality and social justice (Nemanja Krsti'c et al., 2018). In the Islamic view, development is an exhibited when the 'daruriyyat' or human necessities, natural and social resources are securely safeguarded rather than chasing for wealth and luxury advancement. Good deeds and knowledge are the adding value to human life that ties the progress and pursuit of happiness as part of human responsibility live on earth. Practicing virtues would eventually bring the value of helping each other for the sake of brotherhood, securing families, living a moderate lifestyle that avoid waste and over-consumption. It is essential to understand the impact of sustainable social development religious based on harmonious life.

Historically, the effort of sustainable social development started with the design by prophet Muhammad (pbuh) when he migrated from Mecca to Medina. Prophet Muhammad (pbuh) was a Rabbani leadership model, who indicates the acceptance of the oneness or unity of Allah, delivers one single direction in ensuring a unified spirit in adhering to 'Shariah Islamiyyah'. Shariah governance is about the responsibility of the management to develop and adopt an all-inclusive culture of Shariah compliance within the organisation. An inclusive culture of Shariah compliance refers to how the system observes with the Shariah principles in its overall state governance operations (Ruzian Markom, 2018).

Prophet Muhammad (pbuh) designed the framework of social justice to bring harmonies life by his moral teachings (Ahmad Hasan, 1971). The effort led to settle down the economic problem faced during the first year of migration. The only reliable way to do by launching the concept of Islamic 
brotherhood so that they started to think every Muslim as their brother regardless of the colour, caste and clans. This notable policy showed that prophet Muhammad (pbuh) was a successful leader, undoubtedly. The notion of Islamic brotherhood is an optimal solution for this problem that unity is the foundation for harmonious life of society. This work provided proof that binding the humanitarian relationship between Muslims with the Jews in Medina which may grow up a positive way as a progressive society (Al-Ariri, A.Y. (2006); Mustafa Monjur, 2011).

Among the key issues in the Prophet's lessons was the concept of love and brotherhood. He taught the companions about being careful while dealing with one another in their day-to-day life. The prophet Muhammad (pbuh) endeavoured to unite the followers together upon the same shared values starting from individual, family and community levels. He explained the rights for each category and ensured the individual Muslim community to uphold the duties towards one another in the society. The companions sacrificed their riches to others for the sake of Allah and worked together as believers towards fulfilling the goals of the 'ummah' (Miiro Farooq \& Siraje Abdallah Ssekamanya, 2018).

The approaches of humanitarian relationship may offer a viable solution that empowerment is one of the mechanisms used to promote employee development in an organisation. In the Islamic point of view, the empowerment signifies the form of discussion namely as Syuratic (collective) decision making that applied in all levels, regardless of its importance value within the Muslim society. It applies collectively to decision making on social matters (Salleh, 1992). In the Qur'an, the term syura close to its meaning: "And who (conduct) their affairs by mutual consultation" (Ash-Syura (42), Verse.38:487).

Some studies have suggested employees' empowerment may create a sense of belongingness and ownership towards the central organisation. Elevating the followers' empowerment are the typical situation when dealing with these problems that Malay leaders are utilising the party's premise by guiding knowledge and party programs. The statements made by the following study participants describe this effort:

\section{"Send him an organisational management course" (private interview $P_{1} U$ )}

"There is no other way than to take courses, to organise activities" (private interview $P_{1} U$ )

"Party Empowerment unit provides management courses to branch-level of leadership ... The Executive Council through the Party Empowerment Unit will create organisational management programs. There are many modules, introduction to the party, introduction to party organisation, introduction to the constitution, introduction to the workers' movement, system failure whatever it is. That is all, usually made after the election of a new committee' members." ( private interview $\mathrm{P}_{4} \mathrm{P}$ )

"There are programs made, and courses made, UMNO training bureau and sometimes we are under the bureaucracy and so on" (private interview $P_{7} U$ )

"Yes, there are some, first of all in terms of party empowerment there are academy units to train party officers from the organisation's side and so forth and party stabilisation work" (private interview $P_{5} U$ )

Empowerment of employees is a current technique that has been practically used by managers to escalate productivity through enhancement of employee's commitment pertaining the organisation and vice versa. Thomas \& Velthouse (1990) consider psychological empowerment as a factor of internal inspiration and motivation that exhibits the active role of employees in the organisation to improve the skills in an organisation. Leaders strive to provide specialised training or courses to their party followers to improve their efficiency and ability to perform party work. The following facts describe the enhancement of employee's commitment:

"... people will think he's involved in making decisions. So he'll work on his own, and if we go, he'll do it by force if he works hard. But when she is involved in the decision-making process, she feels that this is 
her decision, so with her motivation for her work she becomes more motivated" (private interview $P_{4} P$ )

Leaders also highlight the implementation of skills from the standpoint of engaging followers in discussions and allowing followers to make suggestions. Leaders also allow followers to make decisions together. Through this way, many problems can be solved, and the followers are more dedicated and passionate about party work. These practices are in line with the statements made by the study participants in the following interviews:

"... the thing I always do is always talk or talk. In my case, I will make sure that whatever we talk about before we do so everyone can sit down once he knows, he understands, and he can give his views and contributions. So thank God so far the result of us always discussing this is that a lot of problems can be solved and things go well. I am open to meet members for views, comments and so forth" (private interview $P_{4} P$ )

In Islam, this concept of encouraging collective discussion is called a meeting or 'syura'. In this principle, each member of the organisation has the right to express his or her opinion, and the leader is responsible for listening to and executing the results of the collective agreement (Sjadzali, 1993).

Leadership responsibilities in the form of mentoring, leaders strive to ensure that party programs are in line with knowledgeable and agreed plans. The effort can be seen based on the observations and interview statements obtained by the researchers. They are as follows:

"With talks, we start with primary, secondary, and every branch we have PAST and headquarters, and at those centres, we have "tarbiyah centres" (private interview $P_{5} P$ )

"We must immerse them not only in the spirit but in the knowledge and understanding of the struggle and the meaning of the struggle" (private interview $P_{5} P$ )

Malay leaders educate their followers by establishing religious centres and religious institutions. Through this approach, followers will continue to receive ongoing guidance from leaders. The following statement describes the efforts of political leaders in society:

"We start with a role model. For example, our leader, the late spiritual leader Nik Aziz Bin Nik Mat, he has always taught that the culture of knowledge is the concept of Iqra 'that we have cultivated. Let's see in Terengganu, Tuan Guru Abdul Hadi, Tuan Guru Harun Taib and outside Terengganu, Ustaz Harun Din and there are huts, mosques and so on". (private interview $P_{5} P$ )

Among the efforts of PAS has made in its political struggle can be seen in the following statements:

"Calling mankind to the Shari'ah of Allah and His Prophet's Sunnah through oral preaching, writing and practice." (private interview $P_{5} P$ )

"Fighting Islam as a belief and Shari'a and making it a political and national guide and introducing Islamic values in the pursuit of justice and progress in all areas including government and administration, economics and social and education." (Clause 6: PAS Constitution, Amendment 2011)

The leaders represented different hierarchical levels in the organisations who had numerous areas of duty and responsibility. From an Islamic viewpoint, the standpoint of the worldly mission, affirm that leadership has to put commitment in fulfilling the responsibility. In short, it is a requirement to do a collective work for well-being of the whole society through committing goodness ('Amr Bil Ma'roof) and forbidding evil (Nahi-Al-Munkar) (Lari, 1999). In the Islamic leadership model, leaders pursue a vision of establishing a society that is, welfare-oriented, egalitarian, and free from discrimination, oppression and exploitation (Mir, 2010). 
The unity of the people has had various effects on the overall social, economic and political direction. Positive effects include the leaders particularly can empower the people by bestowing them autonomy through sharing power, promote their energy and determination in coping state development. Conversely, the adverse effects, which may be faced fearlessly using an Islamic vision to serve humanity in general, include foreign interference in the political direction and change the landscape of Malaysian society identity. These reproduced by the development of the information technology that has freedom of receiving universal information through borderless worlds such as internet usage, virtual social connections, and so on. Besides, the role of the media challenges the political leaders' role in elevating Islamic values in society.

Overall, the position of Malay political leaders to struggle and instil the Islamic fundamental work ethics now can be accepted by the community, although the implementation is still not wholly Islamic. The majority of non-Muslims, especially the Chinese community, cannot accept the Malays and Islam that dominate and become pillars of politics (James Chin, 2018). Political leaders do the pervasiveness of coalitions or set alliances as mechanisms of political influence within organisations, by convincing peers, subordinates, superiors and outsiders to join forces to pursue their common interests. Hence, after the 14th general election, PAS and UMNO began to create history by signing a political cooperation charter. This approach shows a positive move which officially marked the start of the political collaboration between the two largest Malay/Muslim-based parties in the country.

\subsection{Holistic development of catalysts of progress}

The Islamic Declaration on Sustainable Development (IDSD) (2012) upholds that the ethical norms of Islam imbedded the vision of economic development. As the natural resources are considered as amongst the greatest gifts from God to whole humankinds, hence it is part of the objective of ecosocial system development in emphasising the collective responsibility in utilizing, allocating and preserving this whole nature. In Islam, environmental protection, and the use of natural resources for development purposes should take into account the social aspects. Therefore, human beings have the right to use natural resources in accordance with God's decree without damaging the environmental ecosystem. As a Muslim who understands the responsibilities of the caliph should take a harmonious approach to achieve sustainable development by preserving and protecting the existing natural environment. (Al-A'raf:74; Mohd Rizal Muwazir @ Mukhazir et al., 2006). A response to the human necessity is said to consider the notion of sustainable development to balance environmental protection with a social-economic development (Chiesure \& Groot, 2003). The categories of human needs are numerous and they are classified in term of variances of goods, individual and social services related to health, employment, education, housing facilities (Aburounia \& Sexton, 2006), trainings, establishing relationships and also include the environments for guaranteeing an acceptable life standard for all people (Khalfan, 2002). The definition of sustainable development highlight human needs to be given by the World Commission on Environment and Development (WCED, 1987).

In an Islamic point of view, since human beings are created in the combination of spiritual and physical mould, their needs are also categorised into those two aspects. They need to satisfy their basic needs of spiritual by believing and having faith in God, while to satisfy their physical needs by making the best use of other creations and resources which God has created for them (Aburounia \& Sexton, 2006; Ahmed, 2002). From an Islamic point of view, development becomes sustainable when every action takes into account aspects of balance, moderation, and considerations of social equality. Balance and simplicity develop within the framework of God's government in every creation of His creatures. For example, the creation of the celestial realm and the existence of the earth in a cosmic scheme have shown the aspects of balance and simplicity that produce this life to be on a track that is appropriate to human life. Violations of 'balance' and the occurrence of extremism in human behaviour can change the cosmos of life as a whole (Kamali, M.H., 2016). Deviations in human behaviour from the religious and moral aspects that drive the practice of extremism, including 
actions that damage the earth's ecosystem can cause disruption to the cosmic system.

In the early stage in Madinah, Prophet Muhammad (pbuh) established a city-state as basic guidelines to live in a new society. He formed a blueprint of how Muslims should deal with other religions and ethnicity to manage them in unity as an 'ummah'. He granted minority rights to different religious groups through documents, pledges, and mutual agreements cum succeeded in creating a healthy social ambience. He successfully established a new system to manage the development of both spiritual and material growth of the different religious groups living under the Islamic rule. Historians of medieval Islam articulate that the Constitution of Medina as a window into the political context and social dynamics of the early Muslim community. The interaction between religious distinctiveness, ethnic politics, community building, and defence potentially find expression in the document and are addressed in varying degrees by the historiographical literature written about this document (Anver Emon, 2001).

The wisdom of the Prophet compiled strategies and using the expertise of others helped him to establish a Muslim state of Medina successfully. A knowledgeable person inherits intelligence who may illustrate his skills in facing the situation he suffered because of his knowledge, beliefs and abilities. The Prophet instantly shifted the name of Yathrib to Medina. The word Medina is the root of "tamaddun" means civilisation. The change describes determination, the people who aspired a civilised society. The written agreement dated in 622 A.D. between the Prophet and community groups in Medina symbolized the establishment of the people of Madina and then transformed into a state and government (Patmawati, 2016). Besides, in following the preceding approach, Malay leaders have also increased their work ethic among their followers by providing space for different followers to contribute to the party, including professionals, religionists and activists from various fields. For PAS, each individual has his skills and expertise. The following excerpts describe the work ethic, as stated in below:

"... Today PAS members have reached one million, each with their skills, expertise. Because in this PAS we have some uniformity or ties to other specialities, for example, 'lawyer' in Terengganu here he has 'group lawyer', 'usrah' and so on, there is a 'group' doctor ... They use his skills and expertise, his wisdom to help our cause... in PAS, we take advantage of the fact that he is an ordinary person so that he can donate, for example, pasting a poster after a service, he commits...". (private interview $P_{5} P$ )

Also, the leaders gave their followers an understanding of the party's struggle policy because of their knowledge of the party's goals and vision to bring the party's sincerity, experience and sacrifice to the party's ability to regard their struggle as a religious and future demand. Here are such statements:

"When they understand automatically, they form their sincerity, loyalty and sacrifice ... they know it is a demand and a duty ... an investment for them from their contribution to the hereafter ..." (private interview $P_{5} P$ )

In the meantime, the practice of knowledge-based culture was promoted among PAS party leaders through various approaches and was emphasised by the leaders of the party as it was vital for them to meet the challenges of the day as it was a time that required intelligent minds not to be easily deceived and killed with enemy propaganda. According to study participants from the PAS party, Malaysian politics will one day see the fight between Muslims and secularists, thus seeking to prepare the next generation of leaders by enhancing their mastery of knowledge. The statements quoted in the interview are as follows:

“... my political prediction is that this PAS will soon clash with the DAP in Malaysia, the clash between Islam and secularism ... that's why we have to be truthful, intellectual because the fight is not a physical fight but an intellectual fight, between Islam and secular. Who can argue well, who can come up with ideas neatly and then people will follow, but if we are not ready, we will lose secularly. That's why I always emphasise knowledge, we as Muslims need to increase knowledge because we have to face the times". (private interview $\mathrm{P}_{4} P$ ) 
In this regard, 'usrah' or group discussion became the main approach for PAS leaders to discuss and exchange views through sitting together in study circle which can generate common values between fellow members and leaders. The ideas that come from appreciating the party's vision can produce the same understanding and thinking. Here are as follows:

"So that's why I emphasise this importance of how important it is to ensure that every PAS branch ...

Branch Muslimat, Branch Youth has their efforts, so when they have their efforts, they can better understand what the struggle is. PAS...". (private interview $P_{2} P$ )

Referring to a speech by the PAS Supporters' Assembly (DHPP) Speaker N Bala Subramaniam at the $62^{\text {nd }}$ PAS Annual Muktamar, he noted that it was PAS's speciality when a small group called 'usrah' played a role in providing understanding to Islam. The 'usrah' is essential on behalf of the DHPP and want 'usrah' to be allowed to them (non-Muslims) so that they can have better understanding about the struggle within this party for the sake of Islam (PAS Muktamar, 2016).

Thus, the misunderstanding of the party's struggle policy can open the door to treason against the party, such as leaking the party's secrets and harming the party. Any member or leader who violates the party's discipline may be subject to disciplinary action (PAS Constitution, 2018) as follows:

“Clause 82: PAS Discipline

1) All PAS members shall:

a) Obey and adhere to the laws and teachings of Islam that are the foundation of PAS.

b) Obey and adhere to the Party Constitution and its Rules and Regulations.

c) Obey and obey the instructions and orders of the Party.

d) Perform the duties assigned to it by the Party as reasonably practicable.

e) Carefully guard all Party secrets.

f) Practice Islamic morals

g) Controls itself against any act that is in the interests of the Party or the interests of the Party.

h) Accepting PAS as the only container of Islamic struggle for itself in this country

Human beings play an essential role in managing natural resources and developing them for the benefit of their lives (Muhammad Syukri Salleh, 2002). As God's word (al-Mulk, 67:15) which means:

"He, it is Who hath made the earth easy for you, and walk in all directions, and eat of His provision, and unto Him, ye will be raised."

The political leadership in the state of Terengganu find several challenges in the light of globalisation, including the absence of an Islamic political direction or the lack of the clarity of social progress landscape. Besides, the political party systems lack administrative leader role models, and rigidity, political awareness among the people is moderate, and the budgets for elevating political awareness and scientific research are low.

The findings of the field studies revealed a moderate level between the political party leadership attributes with Rabbani political leadership work ethics. The results indicate that the political direction needs political leaders' role models. The effort suggests that the elected leadership process in a political party should be revised to ensure they work following Islamic standards. The study concludes with several recommendations that include developing a new, well-defined and integrated political direction. These recommendations are some suggested tools to help modernise and improve political leadership from an Islamic perspective in light of the globalisation of administration. The tools necessitate restructuring the political direction as follows: formulate a new vision which is clear and integrated political orientation, the rights are recognised, and duties and roles are determined. Take unified stances and collective actions to curb foreign interference in the field of politics and its leadership. Political parties or any institutions may take action to organise any political conference to discuss political issues-related reports and administrative management that aim to issue a consolidated statement. Adopt Islamic standard values in the face of global standards and values of 
inclusive and national politics. Prepare role model political leaders, who are prudential and who has faith in the Islamic norms and the state constitution. Develop active community participation in the political process by strengthening and promoting political information in mass media, radio and television.

\section{Conclusion}

In this paper, concept of sustainable development and leadership in Islam was discussed. The term sustainable development has been used differently, depending on the several interpretations, and sometimes contradictory based on the type of organizations and knowledge disciplines. The paper provided a historical perspective on the evolution and importance of leaders in Terengganu political landscape. The political leaders may know the past, understands the reality, and foresees the future is the process which can conclude the presentation of a vision for the policy of national agenda and a guide for its leadership. This phenomenon will affect the concept of the sustainable development. Then, the term sustainable development could be synthesized as the assurance of the future development on progress and evolution of the future generation.

The discussion described and critically analysed how the concept of sustainable development may be developed based on the balancing of political struggle by three factors; building the notion of religious belief as a source of knowledge and guidance; unity is the foundation of a harmonious and sustainable life; and holistic development of catalysts of progress. Rabbani political leadership represents an open political environment to its surroundings. Its dynamism enables it to cope with environmental changes and tries to harmonise and balance the requirements and needs of the community in which they live. The notion of rabbani political leadership inspired the idea how society should be ordered. The Terengganu political leadership who are inspired by rabbani leadership framework practising Islamic teaching for selecting and producing quality human capital. The political leader may take role as a bridge to harmonize the understanding of sustainable development who has power to manage the development in any organizations. Political leaders do the pervasiveness of coalitions or set alliances as mechanisms of political influence within organisations, by convincing peers, subordinates, superiors and outsiders to join forces to pursue their common interests. Hence, after the 14th general election, PAS and UMNO began created history by signing a political cooperation charter and it calls as Muafakat National (National coalition). The results indicate that the political direction needs political leaders' role models. The effort suggests that the elected leadership process in a political party should be revised to ensure they work following Islamic standards. The study concludes with several recommendations that include developing a new, well-defined and integrated political direction.

\section{Acknowledgement}

The authors are grateful to the Ministry of Higher Education, Malaysia, for the financial support granted (FRGS) to cover the research article.

\section{References}

Aburounia, H. \& Sexton, M. (2006). Islam and sustainable development. Proceedings of the $6^{\text {th }}$ International Postgraduate Research Conference, Delft, Netherlands: $3^{\text {rd }} \cdot 4^{\text {th }}$ April.

Abdul Hamid, A. S. (2007). Islamic perspectives on management: What we need to Know and Why. AIM Asian Business Conference. Manila, Philippines, March 2007.

Abu Faris, M.A.Q. (200o). Fiqh Siyasah menurut Imam Syahid Hasan Al-Banna. (M.Z. Yahya, Trans.). Kuala Lumpur, KL: Pustaka Syuhada.

Ahmad, K. (2009). Leadership and work motivation from the cross cultural perspective. International Journal of Commerce and Management. 19(1), pp.72-84. 
Ahmed, A. (2002). Planning for a Sustainable Future from the Islamic Point of View. Response to the State Sustainability Strategy.

A.H.A. Rahman, Syahrin Said, Hailan Salamun, Hamdan Aziz (2018). Sustainable Development from Islamic Perspective. Int Journal of Civil Engineering and Technology. 9(4). 985-992.

Ali, A.J. (2009). Islamic perspectives on leadership: a model. International Journal of Islamic and Middle Eastern Finance and Management. 2(2), pp. $160-180$.

Amir, A. N. (2009). Sistem politik Islam di zaman Nabi Muhammad SAW. Jurnal Usuluddin, 29, 221-252.

Al-Ariri, A.Y. (2006). Analisis Strategi Rasulullah dalam Pembentukan Negara Madinah. Kuala Lumpur: AlHidayah, House of Publishers.

A. Hj Ab Rahman, Wan Ibrahim Wan Ahmad, Nooraihan Ali (2012). Islamic Concept of Social Justice in the Twentieth Century. Advances in Natural and Applied Sciences, 6(8): 1423-1427.

Azmah Abd. Manaf. (2013). Perkembangan politik dan kesannya ke atas pembangunan ekonomi Terengganu antara tahun 1955 hingga 1969. Malaysia Journal of History, Politic and Strategy, 40 (1), 133-154.

Azmi Aziz Mostafa Kamal Mokhtar. (2011). Transisi penting sistem berkerajaan di Alam Melayu: Kes Malaysia. Jurnal Akademika, 81 (2), 79-92.

Borhan, A.J. (2013). Konsep siasah syar'iyyah dan pelaksanaannya dalam konteks Malaysia. Seminar Kebangsaan Perlaksanaan Syariah Syar'iyyah dalam konteks masa kini: Isu dan Cabaran. Melaka: Kolej Universiti Islam Melaka: $21^{\text {st }}$ February.

Beekun, R. I. \& Badawi, J. (1999). Leadership: An Islamic Perspective. Beltsville, MD: Amana.

Cheema, Shahbaz Ahmad (2013). Problematizing the religious basis of Maududi's political theory. Studies on Asia Series $I V, 3(2), 52-82$.

Chiesura, A. \& Groot, R., (2003). Critical natural capital: A socio-cultural perspective. Ecological Economics, 44, 219-231.

Dion, M. (2002). Business ethics and spirituality among Jews, Christians and Muslims. In: T.C. Pauchant (Ed.), Ethics and spirituality at work: Hopes and pitfalls of the search for meaning in organisations Westport, $\mathrm{CT}_{7}$ Quorum Books. (pp. 159-168).

Emon, A. (2001). Reflections on the "Constitution of Medina": An essay on methodology and ideology in Islamic Legal History. UCLA J. ISLAMIC \& NEAR E.L. 1 (1), 103-133.

Farooq, M., \& Ssekamanya, S.A. (2018). The Role of Education in the Development of Spirituality and Community Empowerment: Lessons from the Approach of Prophet Muhammad (SAW). Interdisciplinary Journal of Education, 1 (2), 239-249.

Hasan, A. (1971). Social Justice in Islam. Islamic Studies, 10 (3), 209-219.Beekun, R. I. (20o8). Leadership from an Islamic Perspective: Integrity and Justice. The University of Nevada.

Hamdan Aziz. (2012). Politik dan Kerajaan. Kuala Lumpur: Freemind Horizons Sdn. Bhd.

Indah Maisuri. (2015). Makalah Studi Masyarakat Melayu Sistem Politik Dan Pemerintahan Melayu. Program Studi Hubungan Internasional Fakultas Ilmu Sosial Dan Ilmu Politik. Universitas Riau Pekanbaru.

Islamic Declaration on Sustainable Development (within the Framework of the Islamic World's Participation in the Rio+2o Summit) 2012. https://www.isesco.org.ma/wp-content/uploads/2015/o5/5env-decla_en.pdf

Jabnoun, N. (1994). Islam and Management. Kuala Lumpur, Malaysia: Institut Kajian Dasar.

James Chin (2018) From 'ketuanan' Melayu to 'ketuanan' Islam: UMNO and the Malaysian Chinese, Final Breakup: UMNO and the Chinese in GE14'. In: Welsh, B (Ed) The End of UMNO? Essays on Malaysia's Former Dominant Party New and Expanded Post GE (14 Edition). Petaling Jaya: SIRD. 255-304

Joseph Masciulli, Mikhail A. Molchanov, W. Andy Knight (2009). The Ashgate Research Companion to Political Leadership. Routledge

Kamali, M.H. (2016). Islam and sustainable development. Islam and civilisational renewal, Malaysia: International Institute of Advanced Islamic Studies, 7 (1), 8-26

Khalfan, M. M. A.; Bouchlaghem, N. M.; Anumba, C. J.; and Carrillo, P. M. (2002), "A Framework for Managing Sustainability Knowledge, the C-Sand Approach”, eSM@RT 2002 Conference, to be held at University of Salford on 19-21 Nov. 2002.

Lari, S. M. M. (1999). Imamate and leadership. https://www.al-islam.org/printpdf/book/export/html/12934

Mansor, S. (2010). Kemunculan Kepimpinan Melayu baru di Tanah Melayu pada Awal abad ke-2o / Dr. Suffian Mansor. In: The $7^{\text {th }}$ International Malaysian Studies Conference (MSC7).

Maududi, S. A. A. (200o). Khilafat wa Malookeyat, Lahore: Idara Tarjumanal Quran.

Mir, A. M. (2010). Leadership in Islam. Journal of Leadership Studies, 4(3), 69-72.

Metcalfe, B. D. \& Murfin, T. (2011). Leadership, social development and political economy in the Middle East: An Introduction. In: B. D. M. A. F. Mimouni, (Ed.) Leadership Development in the Middle East. Cheltenham: Edward Elgar Publishing Limited, pp. 1-6o. 
Mohd Rizal Muwazir (2006), Tanggungjawab Sosial Korporat: Tinjauan dari Perspektif Pengurusan Islam, Dimensi Pengurusan Islam: Mengurus Kerja dan Mengurus Modal Insan, Ab. Mumin Ab. Ghani and Fadillah Mansor (eds.). Kuala Lumpur: University of Malaya Press, pp. 23-43.

Mustafa Monjur. (2011). An analysis of the practices of Prophet Muhammad (s.a.w.) in resolving conflicts. Journal of the Bangladesh Association of Young Researchers, 1 (1), 109-125.

Nik Haslinda Nik Hussain. (2014). Undang-undang bagi Diri Kerajaan Terengganu, 1911 dan pengekalan status Melayu Islam Terengganu. Melayu: Jurnal Antarabangsa Dunia Melayu. 7 (1). 41-59.

Nik Mustapha hj. Nik Hassan. (200o). Towards developing quality and productive personality. Al-Nahdah: A Journal of the Regional Islamic Da 'wah Council of Southeast Asia and the Pacific 18(3): 52-55.

Nemanja Krsti'c, Jelena Dini'c \& Danijela Gavrilovi. (2018) Religiosity and Informal Economic Practices in Southeastern European Societies. Religions, 9 (295).

Nor 'Azzah Kamri, Siti Fairuz Ramlan, \& Azharsyah Ibrahim. (2014). Qur'anic Work Ethics. Journal of Usuluddin. 40, 135-172.

Noor Sulastry Yurni Ahmad \& Nor Azila Mohd Azidin. (2013). Transisi kontra hegemoni dalam budaya politik Melayu di Malaysia. Jurnal Antarabangsa Dunia Melayu, 6(1), 120-137.

Perlembagaan PAS. (2018). Perlembagaan Parti Islam Se Malaysia (PAS) (PINDAAN 2011) https://pas.org.my/perlembagaan-pas/

Patmawati. (2016). Inter-religious relations in the period of Prophet Muhammad. AL-ALBAB. 5 (2), 175 -193.

Ramli Awang. (1997). Tasawwur Rabbani: Menurut Al-Quran dan A-sunnah. Kuala Lumpur: Al-Hidayah publisher.

Ruhani Tuan Shariff. (1984). Pentadbiran agama Islam di Terengganu dari tahun 1911 hingga 1930-an. JEBAT: Malaysian Journal of history, politics and strategic studies, 13: 119-148.

Ruzian Markom. (2018). The role of law and Shariah Governance In Islamic finance towards social justice in diversity. Diponegoro Law Review, 3 (2), 142-153.

Salleh, M.S. (2002). Pembangunan Berteraskan Islam. Kuala Lumpur, KL: Utusan Publications \& Distributors.

Salleh, M. (1992). A model of sustainable development in comprehensive Islamic framework: The Canadian economic, an association meeting, the Canadian learned societies conference, www.Islamic-finance.net.

Salamun H., Rahman, A.A., Aziz, H. \& Rashid, R. (2018). Malay leadership pattern in Malaysian politics. Journal of Social Sciences Research. 4(12), 451-458. https://doi.org/10.32861/jssr.412.450.458

Salamun, H. \& S. Shah (2012). Investigating the concept of Rabbani leadership practices at secondary schools in Malaysia. Business \& Management Quarterly Review, 3 (2):33-47.

Sjadzali, M. (1993). Gejala Krisis Integritas Ilmiah di Kalangan Ilmuwan Islam. In Islam: Realitas Baru dan Orientasi Masa Depan Bangsa, Jakarta: Universitas Indonesia Press.

Stavrou, Eleni \& Ierodiakonou, Christiana. (2011). Flexible work arrangements and intentions of unemployed women in Cyprus: A Planned Behaviour Model. British journal of management. 22, 150-172.

Stogdill, R.M. (1974). Handbook of leadership: A survey of the literature, New York: Free Press.

Sulaiman, M. (2013). Islam dan transformasi sosial masyarakat Melayu Malaysia: Suatu kajian eksploratari. Prosiding International Conference on Social Science Research (ICSSR) di Penang, Malaysia. 4-5, Jun.

Thomas, K. W., \& Velthouse, B. A. (1990). Cognitive elements of empowerment: An "interpretive" model of intrinsic task motivation. The Academy of Management Review, 15(4), 666-681.

WCED (1987) Our Common Future, The World Commission on Environment and Development, Oxford University Press, New York. www.salaam.co.uk/islamicfinance 